\title{
NORTHERNMOST RECORDS OF PAGRUS AURIGA (ACTINOPTERYGII: PERCIFORMES: SPARIDAE) AND POMADASYS INCISUS (ACTINOPTERYGII: PERCIFORMES: HAEMULIDAE) IN THE EASTERN ATLANTIC
}

\author{
Rafael BAÑÓN ${ }^{1,2 *}$, David BARROS-GARCÍA ${ }^{3}$, Gonzalo MUCIENTES ${ }^{2,4}$, \\ and Alejandro DE CARLOS ${ }^{3}$
}

\author{
${ }^{1}$ Servizo de Planificación, Dirección Xeral de Desenvolvemento Pesqueiro, \\ Consellería do Mar e Medio Rural, Xunta de Galicia, Santiago de Compostela, Spain \\ ${ }^{2}$ Grupo de Estudos do Medio Mariño (GEMM), Ribeira, Spain \\ ${ }^{3}$ Departamento de Bioquímica, Xenética e Inmunoloxía, Facultade de Bioloxía, Universidade de Vigo, Vigo, Spain. \\ ${ }^{4}$ Centro de Investigação em Biodiversidade e Recursos Genéticos, CIBIO-UP, Vairão, Portugal
}

Bañón R., Barros-García D., Mucientes G., De Carlos A. 2014. Northernmost records of Pagrus auriga (Actinopterygii: Perciformes: Sparidae) and Pomadasys incisus (Actinopterygii: Perciformes: Haemulidae) in the eastern Atlantic. Acta Ichthyol. Piscat. 44 (4): 323-327.

Background. The first records of the redbanded seabream, Pagrus auriga Valenciennes, 1843 (Sparidae), and the bastard grunt, Pomadasys incisus (Bowdich, 1825) (Haemulidae), from Galician waters (NW Spain) are reported herewith. Both findings constitute the northernmost confirmed records of those fishes in the eastern Atlantic. The Galician waters seem to be an important observation point of this phenomenon as evidenced by the high number of new tropical-affinity fishes recorded during the last years in this area.

Keywords: redbanded seabream, bastard grunt, first record, northern limit, Galicia, north-west Spain

Two rare fish species, the redbanded seabream, Pagrus auriga Valenciennes, 1843 (Sparidae), and the bastard grunt, Pomadasys incisus (Bowdich, 1825) (Haemulidae), were caught in Galician waters (NW Spain) by spear fishermen (Fig. 1). The aim of this note was to describe the unusual records of these two southern species found in Galician coastal waters.

Pagrus auriga is a demersal marine fish inhabiting various types of sea bottom, especially rocky bottoms, from the shore to depths of about $170 \mathrm{~m}$ (the closer to the shore the specimens are younger). It is distributed along the eastern Atlantic Ocean, from Portugal to Angola, and around the Madeira, Canary Islands, and Cape Verde Islands. It is also found throughout the Mediterranean Sea, but is very rare along the northern shores of this sea (Bauchot and Hureau 1986, 1990).

Pomadasys incisus is a coastal demersal species inhabiting marine and brackish waters, usually near sandy or muddy substrates, at depths ranging from 10 to $100 \mathrm{~m}$ but most often around $50 \mathrm{~m}$ (Kapiris et al. 2008). It is distributed along the eastern Atlantic Ocean, from Portugal to Angola, and in South Africa, around the Azores,
Canary Islands, and Cape Verde Islands, as well as in the Mediterranean Sea (Bodilis et al. 2013).

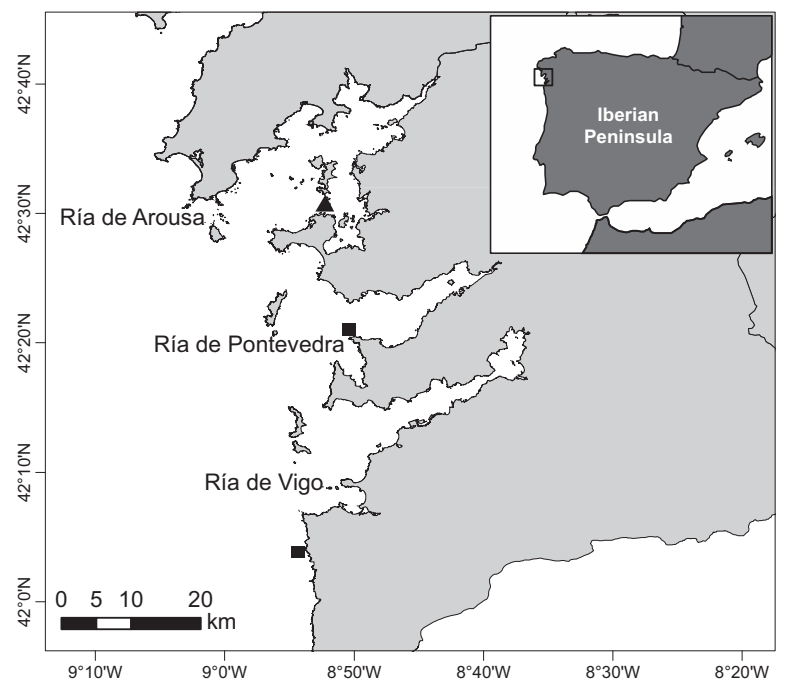

Fig. 1. Sampling area of Pagrus auriga (squares) and Pomadasys incisus (triangle)

\footnotetext{
* Correspondence: Rafael Bañón, Dirección Xeral de Desenvolvemento Pesqueiro, Consellería do Mar e Medio Rural, Xunta de Galicia, Rua dos Irmandiños s/n, 15701 Santiago de Compostela, Spain, phone: (+34) 655220949, e-mail: (RB) anoplogaster@yahoo.es, (DBG) davbarros@uvigo.es, (GM) gonzalo@iim.csic.es, (ADC)adcarlos@uvigo.es.
} 
One specimen of Pagrus auriga was recorded for the first time in August 2005 in A Guarda coast (South Galicia; $41^{\circ} 59^{\prime} 59^{\prime \prime} \mathrm{N}, 8^{\circ} 52^{\prime} 57^{\prime \prime} \mathrm{W}$, and a second individual, of about $2.5 \mathrm{~kg}$ and $65 \mathrm{~cm}$ of total length (Fig. 2), was caught at the end of August 2013 over a sand bottom at $14 \mathrm{~m}$ of depth in front of Cabo Udra (Ría de Pontevedra) at $42^{\circ} 20^{\prime} 26^{\prime \prime} \mathrm{N}$, $8^{\circ} 50^{\prime} 15^{\prime \prime} \mathrm{W}$. One specimen of Pomadasys incisus was caught by a spear fisherman on 15 March 2014, in Pedras Sálvores, near O Grove (Ría de Arousa), at $42^{\circ} 29^{\prime} 48^{\prime \prime} \mathrm{N}$, $8^{\circ} 54^{\prime} 29^{\prime \prime} \mathrm{W}$ at $12 \mathrm{~m}$ depth hiding in a rock crevice (Fig. 3). Only the specimen of $P$. incisus was preserved frozen, scaleless and eviscerated. After defrosting, the fish was fixed in $10 \%$ formalin, transferred to $70 \%$ ethanol, and finally deposited in the fish collection of the Museum Luis Iglesias de Ciencias Naturais of Santiago de Compostela (Galicia, Spain) with the reference number 25008.

The specimens of Pagrus auriga were identified by photographs, based mainly to the typical coloration of this species, silvery pink with 4 or 5 dark red transverse bands alternatively wide and narrow (Bauchot and Hureau 1986). The identification of fishes by photographs is a valid method, especially when is carried out by expert taxonomists, and is even used in the elaboration of checklists (Wirtz et al. 2008).

The main morphometric and meristic characters were taken on the preserved specimen of Pomadasys incisus, after defrosting, following Bodilis et al. (2013) (Table 1). These data are in agreement with measurements and counts reported by other authors describing this species (Serena and Silvestri 1996, Kapiris et al. 2008, Bodilis et al. 2013). The specimen showed the main distinctive characters of the species: oblong body, compressed, tapering posteriorly; coloration brownish back, silvery belly, with a dark blotch on the upper corner of the operculum; preopercle with a slightly concave and serrated posterior margin; large head, contained 3.1 times in the standard length; small and slightly oblique mouth; two clearly visible pores on the tip of the chin, and a short, shallow groove behind.

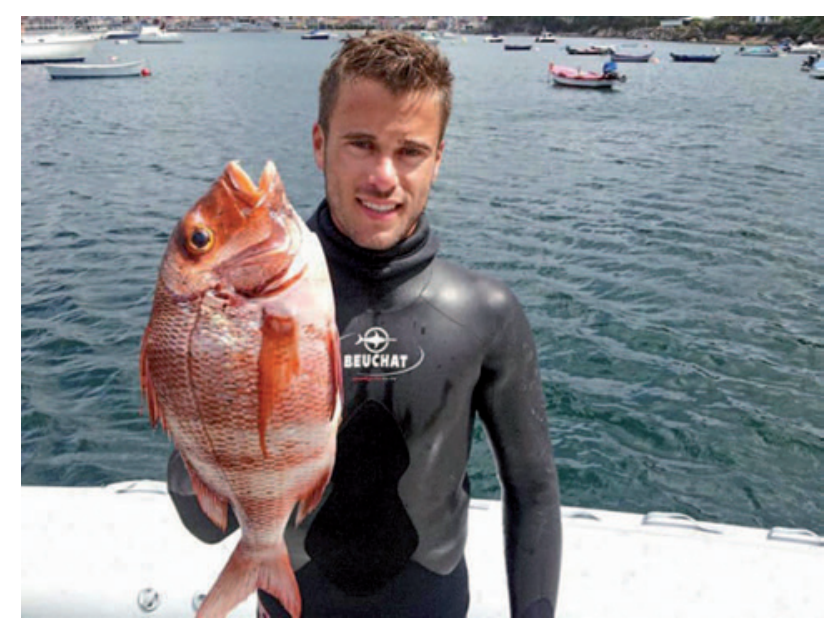

Fig. 2. A specimen of Pagrus auriga captured from Galician waters (NW Spain)

A sample of muscle from the specimen of Pomadasys incisus was taken for DNA extraction, PCR amplification and sequencing of the standard $5^{\prime}$ barcoding region of the mitochondrial COI gene. All procedures were performed as previously described (Bañón et al. 2013) using the primers pair FF2d-FishR2_t1 (Ivanova et al. 2007). A 655 bp nucleotide sequence was deposited in the GenBank repository with accession number KM017063, and was used as query for the identification of the specimen in the Barcoding of Life Data Systems ${ }^{*}$ and GenBank ${ }^{* *}$ repositories. In both searches, the sequence was unambiguously matched to $P$. incisus. To explore the phylogenetic relations a sequence alignment was built using COI sequences from the related species Pomadasys olivaceus (Day, 1875) and Pomadasys perotaei (Cuvier, 1830), which were used as outgroup, and the number of base differences per site was calculated, with a total of 645 positions in the final dataset. The evolutionary history was inferred using the neighbor-joining method (Saitou and Nei 1987) and the confidence limits were tested though a bootstrap procedure (Felsenstein 1985). The evolutionary distances

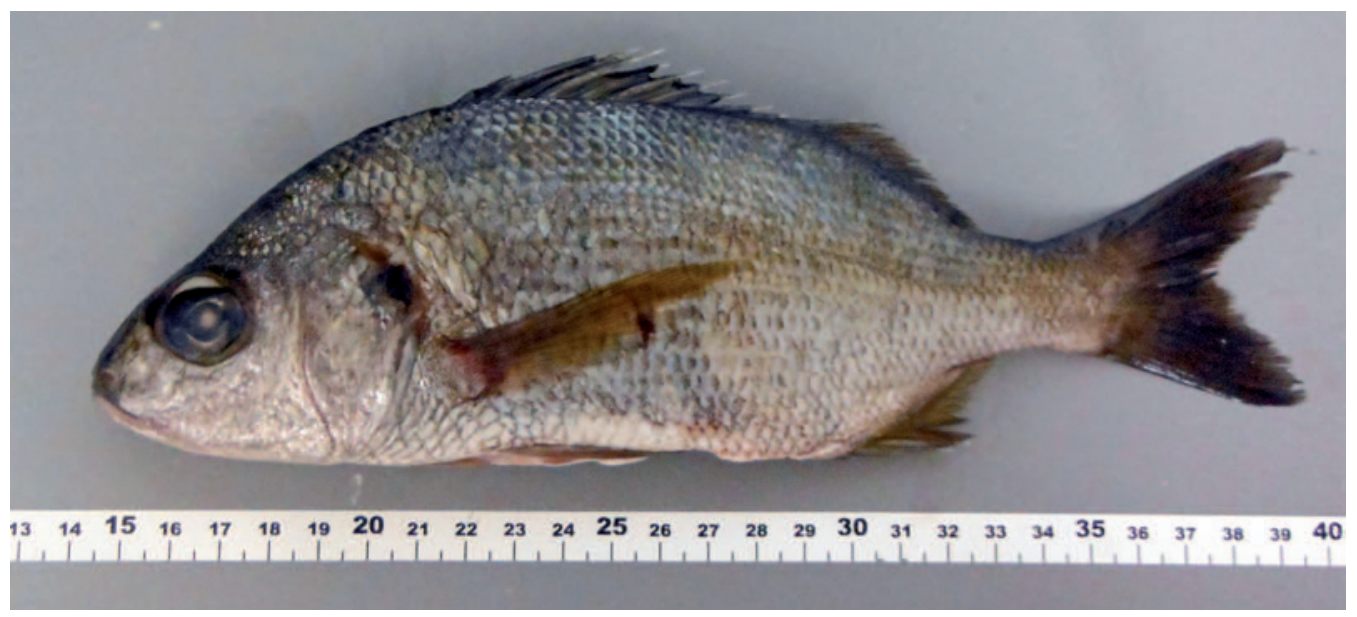

Fig. 3. A specimen of Pomadasys incisus captured from Galician waters (NW Spain)

\footnotetext{
${ }^{*}$ http://www.boldsystems.org/index.php/IDS_OpenIdEngine.

${ }^{* *}$ http://blast.st-va.ncbi.nlm.nih.gov/Blast.cgi.
} 
were computed using the $p$-distance method (Nei and Kumar 2000). The evolutionary analyses were conducted in MEGA5 (Tamura et al. 2011).

The resulting phylogenetic tree (Fig. 4) clustered in a strongly supported clade the sequence of the Galician specimen with other Pomadasys incisus sequences, and separated them from the clade formed by the closely related species $P$. olivaceus.

Both species are unreported in the last revision of the marine ichthyofauna of Galicia (Bañón et al. 2010) and constitute new records of tropical affinity fishes northwards of their habitual distribution range and a new extended northern limit for their distribution in the eastern Atlantic. The presence of these and other tropical and subtropical fishes recently reported may involve various phenomena such as a recent warming of the Galician waters of $0.24^{\circ} \mathrm{C}$ by decade since 1974 (Gómez-Gesteira et al. 2011), the decrease in the extension and intensity of the upwelling season and, conversely, the increase in the extension and intensity of the downwelling season which favours the development of the poleward current, as discussed in previous studies (Bañón et al. 2002, Bañón and Santás 2011).

Morphometric and meristic parameters and weight of Pomadasys incisus according

Table 1 to different bibliographical sources

\begin{tabular}{|c|c|c|c|c|c|c|c|c|c|}
\hline & \multirow{3}{*}{ Parameter } & \multicolumn{2}{|c|}{ This study } & \multicolumn{4}{|c|}{ Bodilis et al. 2013} & \multicolumn{2}{|c|}{$\begin{array}{c}\text { Serena } \\
\text { and Silvestri } 1996\end{array}$} \\
\hline & & Empirical & Relative & Empirical & Relative & Empirical & Relative & Empirical & Relative \\
\hline & & {$[\mathrm{mm}]$} & {$[\% \mathrm{SL}]$} & {$[\mathrm{mm}]$} & {$[\% \mathrm{SL}]$} & {$[\mathrm{mm}]$} & {$[\% \mathrm{SL}]$} & {$[\mathrm{mm}]$} & {$[\% \mathrm{SL}]$} \\
\hline \multirow{20}{*}{ 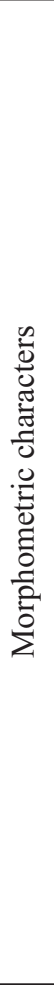 } & Total length & 260 & & 202 & & 179 & & 219 & \\
\hline & Fork length & 234 & & 192 & & 163 & & - & \\
\hline & Standard length & 206 & & 167 & & 145 & & 182 & \\
\hline & Dorsal fin base length & 99 & 48.1 & - & - & - & - & 88 & 48.4 \\
\hline & Pectoral fin length & 62 & 30.1 & 48 & 28.7 & 43 & 29.7 & 53 & 29.1 \\
\hline & Pelvic fin length & 40 & 19.4 & 31 & 18.6 & 27 & 18.6 & 34 & 18.7 \\
\hline & Anal fin base length & 30 & 14.6 & - & - & - & - & 32 & 17.6 \\
\hline & Pre-dorsal length & 72 & 35.0 & 64 & 38.3 & 59 & 40.7 & 71 & 39.0 \\
\hline & Pre-pectoral length & 70 & 34.0 & 56 & 33.5 & 48 & 33.1 & - & - \\
\hline & Pre-pelvic length & 80 & 38.8 & 64 & 38.3 & 50 & 34.5 & - & - \\
\hline & Pre-anal length & 141 & 68.4 & 111 & 66.5 & 96 & 66.2 & - & - \\
\hline & Body depth & 73 & 35.4 & 54 & 32.3 & 48 & 33.1 & 66 & 36.3 \\
\hline & Body width & 28 & 13.6 & 16 & 9.6 & 12 & 8.3 & - & - \\
\hline & Caudal peduncle height & 20 & 9.7 & 16 & 9.6 & 16 & 11.0 & 19 & 10.4 \\
\hline & Head length & 67 & 32.5 & 55 & 32.9 & 44 & 30.3 & 61 & 33.5 \\
\hline & Eye diameter & 16 & 7.8 & 14 & 8.4 & 13 & 9.0 & 16 & 8.8 \\
\hline & Mouth length & 17 & 8.3 & - & - & - & - & 15 & 8.2 \\
\hline & Inter-orbital distance & 21 & 10.2 & 17 & 10.2 & 14 & 9.7 & - & - \\
\hline & Pre-orbital length & 18 & 8.7 & 16 & 9.6 & 12 & 8.3 & 19 & 10.4 \\
\hline & Post-orbital length & 32 & 15.5 & 23 & 13.8 & 20 & 13.8 & 29 & 15.9 \\
\hline \multirow{8}{*}{ 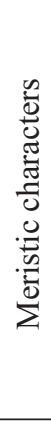 } & Dorsal fin rays & $\mathrm{XII}+17$ & & $\mathrm{XII}+16$ & & $\mathrm{XII}+16$ & & $\mathrm{XII}+16$ & \\
\hline & Pectoral fin rays & 17 & & 14 & & 13 & & - & \\
\hline & Anal fin rays & $\mathrm{III}+13$ & & $\mathrm{III}+13$ & & $\mathrm{III}+12$ & & $\mathrm{III}+13$ & \\
\hline & Ventral fin rays & $\mathrm{I}+5$ & & - & & - & & - & \\
\hline & Pored scales in lateral line & - & & 56 & & 56 & & 56 & \\
\hline & Scales above lateral line & - & & 7 & & 6 & & 8 & \\
\hline & Scales below lateral line & - & & 12 & & 10 & & 11 & \\
\hline & Gill-rakers on first arch & - & & 15 & & 12 & & 21 & \\
\hline \multirow{2}{*}{3} & Total weight & - & & 93 & & 73.1 & & - & \\
\hline & Eviscerated weight & 187.5 & & 90.7 & & 67.8 & & - & \\
\hline
\end{tabular}

$W=$ weight. 


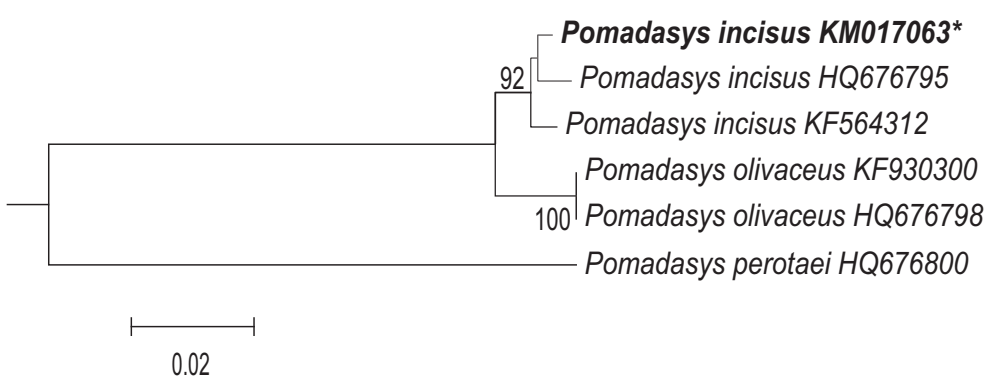

Fig. 4. Neighbor-Joining tree exploring the evolutionary relations of the Galician specimen of Pomadasys incisus (marked with an asterisk) and some congeners; The GenBank accession number is shown with the name of each species; The percentage of replicate trees in which the associated taxa clustered together in the bootstrap test (2000 replicates) is shown next to the branches; The evolutionary distances are in the units of the number of base differences per site

In fact, in the case of Pomadasys incisus, it seems to be a causal relation between its appearance in the Galician coasts in March, just after a previous particularly hard winter, with dominance of southern high-speed winds and storms during about three months, which could favour its northward displacement.

Galicia, an autonomous region located in the northwest corner of the Iberian Peninsula, seems to be a strategic observation point of this phenomenon for the Atlantic European waters. A total of 17 African fish species have been found in the Galician ichthyofauna, most of them recorded for the first time during the last decades (Bañón et al. 2010). Among them, we can also found several other "northern limit" southern species such as Seriola fasciata (Bloch, 1793) (see Bañón and Mucientes 2009), Fistularia petimba Lacepède, 1803 (see Bañón and Sande 2008), or Lagocephalus laevigatus (Linnaeus, 1766) (see Bañon and Santás 2011).

We noted that analogous cases of northward range expansions in the same species and in different areas are becoming increasingly frequent, probably indicating the same response to similar changes in distant marine ecosystems. In the Mediterranean Sea, Pomadasys incisus is a thermophilous species basically restricted to the southern parts (Guerriero et al. 2010), but it has also been encountered in the northern Mediterranean countries since the 1990s (Pastor et al. 2008). Similarly, Pagrus auriga, which is mainly distributed in the south-western Mediterranean, expanded its range also to the NW Mediterranean basin (Matallanas et al. 1993).

Bello et al. (2014) proposed a best practice protocol to be followed by prospective authors of first record notes. This includes checking of regional fish diversity catalogues, designation and deposit of voucher specimens in collections, inclusion of photographs, meristic and morphometric characters, and-whenever possible-the DNA sequences (barcoding) of the specimens.

Although we agree with this protocol, its complete application is only theoretically possible when the specimens are preserved, excluding the cases in which the specimens are not available anymore. In our case, we could apply all these rules to the Pomadasys incisus specimen, but only two of them (photo and check of regional fish catalogues) to Pagrus auriga. In spite of this, the correct identification of this species, due to its peculiar coloration, is out of doubt and in our opinion also validates this first record.

\section{ACKNOWLEDGEMENTS}

We thank the spear fisherman Ivan García Fernández and the secretary of the Asociación Deportiva e Cultural "Raspa", Vicente Pérez Quintela for their kind donation of the specimens. Thanks also to Antonio Otero and José Arcadio, who provided photographs and other data from the catches of Pagrus auriga.

\section{REFERENCES}

Bañón R., Arronte J.C., Barros-García D., Vázquez-Dorado S., de Carlos A. 2013. Taxonomic study of Bathygadidae fishes (Gadiformes) from Atlantic Spanish waters combining morphological and molecular approaches. Zootaxa 3746 (4): 552-566. DOI: 10.11646/zootaxa.3746.4.3

Bañón R., del Rio J.L., Piñeiro C.G. Casas J.M. 2002. Occurrence of tropical affinity fish in Galician waters, north-west Spain. Journal of the Marine Biological Association of the United Kingdom 82 (5): 870-880. DOI: 10.1017/S0025315402006288

Bañón R., Mucientes G.R. 2009. First record of Seriola fasciata (Carangidae) from Galician waters (NW Spain). A new northernmost occurrence in the NE Atlantic. Cybium 33 (3): 247-248.

Bañón R., Sande C. 2008. First record of the red cornetfish Fistularia petimba (Syngnathiformes: Fistularidae) from Galician waters. A northernmost occurrence in the eastern Atlantic. Journal of Applied Ichthyology 24 (1): 106-107. DOI: $10.1111 / j .1439-0426.2007 .00918 . x$

Bañón R., Santás V. 2011. First record of Lagocephalus laevigatus (Tetraodontiformes, Tetraodontidae) from Galician waters (north-west Spain), a northernmost occurrence in the north-east Atlantic. Journal of Fish Biology 78 (5): 1574-1578. DOI: 10.1111/j.1095-8649.2011.02935.x

Bañon R., Villegas-Ríos D., Serrano A., Mucientes G., Arronte J.C. 2010. Marine fishes from Galicia (NW Spain): an updated checklist. Zootaxa 2667: 1-27.

Bauchot M.-L., Hureau J.-C. 1986. Sparidae. Pp. 883-907. In: Whitehead P.J.P., Bauchot M.-L., Hureau J.-C., Nielsen J., 
Tortonese E. (eds.) Fishes of the northeastern Atlantic and the Mediterranean. Vol. 2. UNESCO, Paris.

Bauchot M.-L., Hureau J.-C. 1990. Sparidae. Pp. 790-812. In: Quero J.-C., Hureau J.-C., Karrer C., Post A., Saldanha L. (eds.) Check-list of the fishes of the eastern tropical Atlantic (CLOFETA). Vol. 2. JNICT, Lisbon; SEI, Paris, UNESCO, Paris.

Bello G., Causse R., Lipej L., Dulčić J. 2014. A proposed best practice approach to overcome unverified and unverifiable "first records" in ichthyology. Cybium 38 (1): 9-14.

Bodilis P., Crocetta F., Langeneck J., Francour P. 2013. The spread of an Atlantic fish species, Pomadasys incisus (Bowdich, 1825) (Osteichthyes: Haemulidae), within the Mediterranean Sea with new additional records from the French Mediterranean coast. Italian Journal of Zoology 80 (2): 273-278. DOI: 10.1080/11250003.2012.730555

Felsenstein J. 1985. Confidence limits on phylogenies: An approach using the bootstrap. Evolution 39 (4): 783-791. DOI: $10.2307 / 2408678$

Gómez-Gesteira M., Gimeno L., de Castro M., Lorenzo M.N., Alvarez I., Nieto R., Taboada J.J., Crespo A.J.C., Ramos A.M., Iglesias I., Gómez-Gesteira J.L., Santo F.E., Barriopedro D., Trigo I.F. 2011. The state of climate in NW Iberia. Climate Research 48 (2-3): 109-144. DOI: 10.3354/cr00967

Guerriero G., Di Finizio A., Ciarcia G. 2010. Biological pollution: Molecular identification of non-native species in the central Tyrrhenian Sea. Catrina 5 (1): 41-47.

Ivanova N.V., Zemlak T.S., Hanner R.H., Hebert P.D.N. 2007. Universal primer cocktails for fish DNA barcoding. Molecular Ecology Notes 7 (4): 544-548. DOI: 10.1111/j.1471-8286.2007.01748.x

Kapiris K., Kallias E., Conides A. 2008. Preliminary biological data on Pomadasys incisus (Osteichthyes: Haemulidae) in the
Aegean Sea, Greece. Mediterranean Marine Science 9 (2): 53-62. DOI: $10.12681 / \mathrm{mms} .132$

Matallanas J., Carrasson M., Boix J., Fernandez V. 1993. Occurrence of Pagrus auriga Valenciennes, 1843 in the Catalan Sea. Cybium 17 (1): 79-80.

Nei M., Kumar S. 2000. Molecular evolution and phylogenetics. Oxford University Press, Oxford, UK.

Pastor J., Astruch P., Prats E., Dalias N., Lenfant P. 2008. Premières observations en plongée de Pomadasys incisus (Haemulidae) sur la côte catalane française. Cybium 32 (2): $185-186$

Saitou N., Nei M. 1987. The neighbor-joining method: A new method for reconstructing phylogenetic trees. Molecular Biology and Evolution 4 (4): 406-425.

Serena F., Silvestri R. 1996. First record of Pomadasys incisus (Haemulidae) in the northern Tyrrhenian Sea. Cybium 20 (4): 409-411.

Tamura K., Peterson D., Peterson N., Stecher G., Nei M., Kumar S. 2011. MEGA5: molecular evolutionary genetics analysis using maximum likelihood, evolutionary distance, and maximum parsimony methods. Molecular Biology and Evolution 28 (10): 2731-2739. DOI: 10.1093/molbev/msr121

Wirtz P., Fricke R., Biscoito M.J. 2008. Coastal fishes of Madeira Island-new records and an annotated check-list. Zootaxa 1715: 1-26.

Received: 30 July 2014

Accepted: 16 September 2014

Published electronically: 31 December 2014 